\title{
On the causes of the partition of Central Africa, 1875-85
}

\begin{abstract}
DICK FOEKEN
African Studies Centre, PO Box 9555, 2300 RB Leiden, The Netherlands

ABSTRACT. This article deals with the partition of Central Africa, as it took place between 1875 and 1885 . First of all, a brief summary is presented of the partitioning process, involving the rivalries between the actors concerned, the territorial conflicts arising from it, and the diplomatic processes leading to the treaties between the European powers. Next, 13 theories, all dealing with the causes of the partition of Africa (or the late 19th century's European imperialism in general), are discussed and commented on. This leads to the conclusion that none of these theories is able to explain why at the end of the 1870 s a process of European territorial expansion started in Central Africa. For an explanation of the outcome of this imperialistic process, however, the (combined) theorles are more useful. The final conclusion is that by analysing the processes of European territorial expansion, political geographers can make a useful contribution to the understanding of the late 19th century's imperialism, in particular if this involves territorial rivalries.
\end{abstract}

\section{Introduction}

On 26 February 1885, the German chancellor Bismark read out the Final Act of the Berlin West Africa Conference. The Act contained seven chapters on such matters as free trade and free navigation in the so-called Conventional Free Trade Area (see Figure 1), the abolition of the slave trade in this area, and a declaration regarding future annexations on the African coast (Hertslet, 1967, II: 468-486). Two annexes had been attached to the Berlin Act. The first one concerned the entry of the Association Internationale du Congo (AIC) to the Act. This AIC was a private organization, led by the Belgian King Leopold II, with one major aim: to obtain sovereign rights over an area as large as possible in the Congo Basin. Formally, the entry to the Act meant the recognition, by the other signatories of the Act, of the AIC as a sovereign power. The second annex consisted of a map showing the Conventional Free Trade Area, the territories of France, Germany, Portugal and Zanzibar, as well as the territory of the new state (see Figure 1). With the Berlin Act, the process of the partition of this part of Africa had come to an end. It had started 10 years earlier, when Leopold wrote to one of his collaborators that he intended to find out discreetly whether something could be done in Africa' (Roeykens, 1958: 53) 


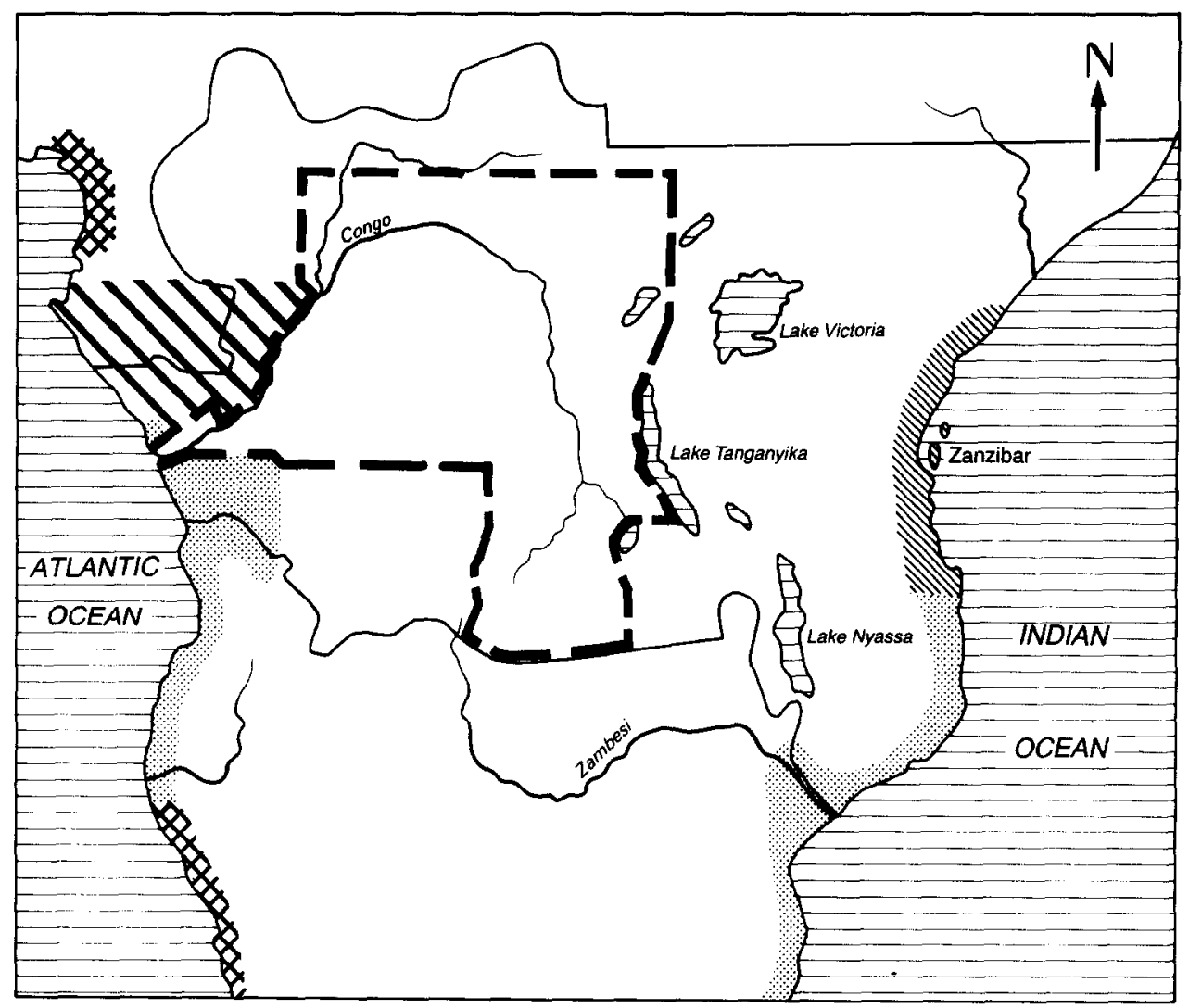

boundary of the Conventional Free Trade Area

boundary of the territory of the Association Internationale du Congo according to the treaty with France of 5 February 1885 and the treaty with Portugal of 15 February 1885.

3 Portuguese territory

X84 territories under German protection

$\$$

French territory

Sultanate of Zanzibar

FiguRE 1. Central Africa after the Berlin West Africa Conference of 1884-85. Source: After Stengers 1971.

The purpose of this article is, first, to describe briefly the process of the partition of Central Africa between 1875 and 1885, and second, to explore how far the various theories and/or explanations regarding the partition of Africa are relevant for this particular case. These theories are many, ranging from general theories explaining the late 19th-century European imperialism, to 'theories' that only explain the motives of one actor in one particular part of Africa. The main conclusions are (1) that the general theories are not able to explain why, in the second half of the $1870 \mathrm{~s}$, a process of European territorial expansion started in the Congo area, and (2) that a political-geographical approach, based on a decision-making analysis, is useful in order fully to understand the process of European imperialism in the late 19th century. 


\section{The partition of Central Africa}

Until 1875 European interests along the West African coast between what are now Cameroon and Namibia were very limited. The only power with territorial interests was Portugal, which held part of present-day Angola. 'The French had a naval base in Libreville (present-day Gabon) and there were two French mission posts, one in Gabon and one near the Congo mouth. In the latter area, several trading houses were established, of various nationalities. The biggest of these trading houses belonged to the Dutch Afrikaansche Handelsvereeniging, but as a whole the West African trade was dominated by the British (Anstey, 1962: 20-31). For decades, this picture had hardly changed. In the mid-1870s, however, Central Africa (which is delimitated as present-day Zaire, Congo, Gabon, the Central African Republic and northern Angola), and especially the Congo River, were at the centre of the interest of (at least) the European geographical associations. All African 'mysteries' such as the big East African lakes, the courses of the Niger and the Zambezi, and the sources of the Nile had been solved (Thomson, 1933: 35-39); only the Congo remained. Moreover, the great African rivers were not only of geographical but also of economic interest because of their (possible) function as main lines of communication.

One man who closely followed all these developments was King Leopold II. Although he was a member of the Royal Geographical Society in London, his prime interest was not geographic but economic: what were the trading possibilities in the newly discovered areas? In the footsteps of his father, Leopold II had tried for many years to obtain overseas interests, either in the form of Belgian concessions or in the form of political control. His one objective was to line the Belgian treasury (Stengers, 1972). Until 1875, however, all his attempts - and there were many-had failed. In that year, news of the fabulous richnesses' of the interior of Central Africa reached Europe through The Times (Roeykens, 1958: 329-331), so Leopold decided to trace his steps towards that part of the world.

Because the Belgian state did not show the least interest in any imperialist venture, the King had to act on his own. In September 1876 he organized an international geographic conference at his palace in Brussels. The conference dealt with the question of how to bring 'civilization' to Central Africa in order to stop the continuing slave trade there. It was decided to establish an international organization with the main objective of opening up Central Africa for western trade and civilization and suppressing the slave trade: the Association Internationale Africaine (AIA). The actual opening up of the Central African interior was to be done by National Committees which had to raise funds and expeditions. The first of these committees was the Belgian one (Roeykens, 1958: 129-130). Under the cover of the philanthropic AIA, and by using his 'own' National Committee, Leopold was now in a position to penetrate the African interior and to establish AIA (read: Belgian) posts there (Thomson, 1933: 57). Between 1877 and 1885, five Belgian expeditions went to East Africa. Although the expeditions were, like Leopold, very ambitious, only two minor posts were established, on both sides of Lake Tanganyika, and at the cost of quite a number of Belgian lives (Brown, 1894; Burdo 1886; d'Ursel 1893).

Despite these failures the King probably did not worry too much, as from 1877 onwards his attention was primarily directed towards the other side of the continent: the Congo mouth. In that year, the world heard for the first time of the spectacular journey of Henry Morton Stanley through Central Africa. Starting on the east coast, he succeeded in reaching the upper stream of the Congo and followed this river down to its mouth. After his return to Europe, he spoke highly of the enormous trading potential in the Congo Basin and the importance of the river itself: 'This river is and will be the grand highway of commerce to West Central Africa' (Stanley, 1885, I: vi). This was the man the King needed and he 
succeeded in placing him in his service. Stanley was to open up the Congo river by establishing posts along its banks and obtain sovereign rights from the local African heads. Formally, Stanley's task was to open up the Congo area in order 'to extend civilization and to search for new outlets for western trade and industry by means of the study and exploration of certain parts of the Congo' (Thomson, 1933: 65-66). For this purpose, Leopold established a new organization, a profit-sharing society called the Comité d'Etudes du Haut-Congo (CEHC), consisting of himself and some European businessmen. Ten months later, however, after the bankruptcy of one of the main participants (the Afrikaansche Handelsvereeniging), Leopold was able to buy out the remaining participants (Anstey, 1962: 79-80). In fact the Comité d'Etudes ceased to exist. Immediately, Leopold had a new name for his 'organization': the Association Internationale du Congo (AIC). The resemblance in name to the AIA was no coincidence. The activities of Stanley aimed at direct political control of the Congo Basin, but by pretending to act under the cover of the AIA or the CEHC, Leopold tried to hold high his image as a philanthropic king who was willing to open up Central Africa at his own expense for the benefit of all (Ascherson, 1963: 116-117). Between 1879 and 1884, Stanley and his many collaborators founded some 35 posts and concluded over 400 treaties in which more than 2000 African leaders ceded their sovereign rights to the AIC in exchange for protection by the AIC (Stanley, 1885, II: 170-178).

Leopold and Stanley had to cope with an important competitor: Pierre Savorgnan de Brazza. Born Italian, Brazza became a French naval officer. He was placed on one of the ships of the French South Atlantic squadron and as such he came to visit Libreville in Gabon for the first time in 1872 . He was immediately fascinated by the Africans and the possibilities of solving the Congo mystery. But even more he wanted to establish a French trade imperium in the region. In 1874, he proposed to organize an expedition towards the Congo. The French government was not at all interested, however. Three years after the defeat of the French army by the Germans, a colonial policy stood very low on the political agenda. There was one man in the French government, however, who was willing to assist Brazza: the Marquis de Montaignac, a friend of the Brazza family, who had just become the new Minister for the Navy (under which the colonies fell at the time). With his help, Brazza and a few companions travelled for three years along the Ogowé River and also reached the upper stream of what was most likely a tributary of the Congo (Brunschwig, 1963: 137-142).

On his return to France in January 1879 , Brazza was welcomed very enthusiastically. Soon he heard of Stanley's departure for the Congo mouth and although he did not officially know what Stanley's (secret) orders were, he had at least an idea (Brunschwig, 1963: 143). However, Montaignac had been replaced and the new Minister for the Navy, Jauréguiberry, was rather disinclined to finance a French expedition. Finally, an agreement was reached: Brazza's expedition was only supported by the government in so far as it was undertaken by the French National Committee of the Association Internationale Africaine (Brunschwig, 1965: 9). In other words, the French government dissociated itself completely from Brazza's expedition (Brunschwig, 1966: 44-45). That could not worry Brazza, however, and it was during this expedition that he concluded his two famous treaties with the Makoko (King) of the Batéké. Based on these treaties, Brazza claimed French sovereign rights over an area bordering the north (right) bank of the Congo (Brunschwig, 1965: 24-33, 47-49, 53-55). But the proclamation of a French protectorate by an officer in the field was one thing; ratification by the French parliament was another. However, during his absence the French political climate had changed from a liberal-economic to a protectionist-colonial course (Elwitt, 1975: 279-283). On his return 
to France in 1882 , there was a widespread call for a new French colonial policy, especially by naval officers and geographers (Wesseling, 1991: 8). In November of that year, the Brazza-Makoko treaties were ratified by the French parliament (Brunschwig, 1963: 161-162).

The ratification had three immediate effects, one in the African field and two in the European diplomatic sphere. The first was a real scramble for the Upper Congo and for the Kwilu-Niari basin between Brazza for France and Stanley for Leopold's AIC (see Figure 2). The Kwilu-Niari basin was of great strategic importance for both actors; for France because it was a much shorter and easier communication line from the Upper Congo to the Atlantic Ocean than the difficult route along the Ogowé, and for the AIC because Leopold could not be sure of the control of the Lower Congo owing to the territorial claims of Portugal (see below). With all his men, supplies and means of transport (steamboats), Stanley had a clear advantage over Brazza. In less than 18 months the AIC succeeded in acquiring political control over almost the whole Kwilu-Niari area, including the coastline, and of the Upper Congo up to Stanley Falls (present-day Kisangani), about $1500 \mathrm{~km}$ upstream from Leopoldville (Grant Elliott, 1886: 105-112; Stanley, 1885, I: 470-518, II: 16-166). In contrast, the French founded only three posts in the Kwilu-Niari area and a few on the right bank of the Congo (Coquery-Vidrovitch, 1969: 48-138).

The second consequence of the ratification was renewed negotiations between Portugal and Britain about the Portuguese territorial claims in the region, which included the Congo mouth. The Portuguese claim was very old and was based on the 'right of discovery' in 1482 (Axelson, 1967: 38-41). But Britain, for centuries Portugal's protector, had always refused to recognize Portuguese control north of the Logé River (about $200 \mathrm{~km}$ south of the Congo mouth), first because of the Portuguese refusal to suppress the overseas slave trade (Anstey, 1962: 10, 40), and second, because of the Portuguese protectionist colonial policy and the growing British trading interests in the region (Newbury, 1988: 49). With the French ratification of the Brazza-Makoko treaties, however, a completely new situation emerged. Suddenly, there was a danger of a French trade monopoly in the Congo area, forming a great threat for the existing and future British trade. In other words, because of the French return towards a policy of formal imperialism in West Central Africa, the British policy of informal imperialism-based on the doctrines of free trade and paramountcyhad become worthless (Sanderson, 1988: 212). In the perception of the British government, the best alternative was to place Portugal at the Congo mouth, in return for far-reaching Portuguese concessions regarding trade and navigation in all Portuguese possessions in Africa (Sanderson, 1988: 205). Although the negotiations were lengthy and difficult, the final result was the Anglo-Portuguese treaty of 26 February 1884, in which Britain recognized the Portuguese claims on both the south and the north banks of the Lower Congo (Hertslet, 1967, III: 1004-1005). For Leopold it meant that his outlet to the sea by means of the Lower Congo was blocked.

The third consequence of the ratification of the Brazza-Makoko treaties was a diplomatic offensive by Leopold in order to get his AIC recognized by the major powers as a sovereign state. Although his strongholds in Africa might be useful to bar the French and Portuguese routes in Africa, it might all turn out to be worthless unless the powers were willing to recognize the sovereign rights the AIC had obtained from the African leaders, i.e. to recognize the flag of the AIC as that of a friendly nation. Because the European powers had rather mixed feelings about Leopold's 'African adventure' (to say the least), the King decided first to approach the United States. The choice was not coincidental: Liberia was founded by an American private, philanthropic organization; there were millions of negroes living in the United States; and Stanley, although born in Britain, was an American 


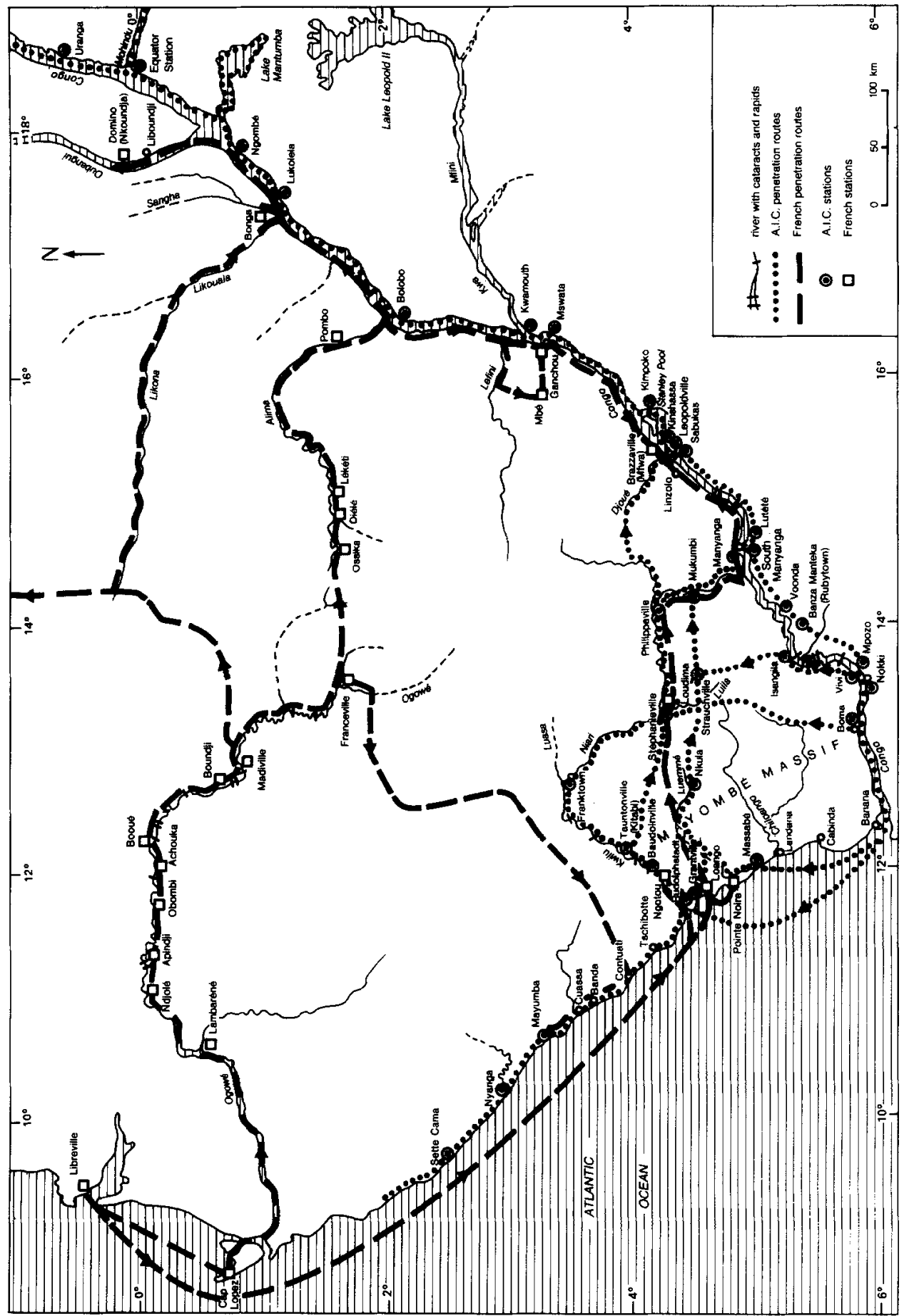

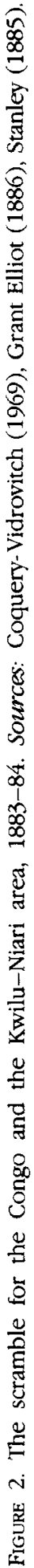


citizen (Thomson, 1933: 147-148). Leopold's envoy succeeded, albeit by misleading and even cheating the American government (Crowe, 1942: 80; Stengers, 1971: 128; Thomson, 1933: 153-154). On 22 April 1884, the American recognition of the AIC as a sovereign power became a fact (Bontinck, 1966: 173-196). The British Foreign Office simply commented that 'the United States' Government have committed a great act of folly' (Stengers, 1963: 157).

The following day, 23 April 1884, Leopold won a second victory in the form of a convention with France in which France promised to respect the stations and territories of the AIC, while Leopold gave France a right of pre-emption on the AIC possessions in Africa (Hertslet, 1967, II: 562-563). The latter meant de facto that if, for whatever reason, Leopold should be forced to dispose of his African possessions, France would be given the right to make a first bid. This proved to be a diplomatic master move because now Britain and Germany were confronted with possible French domination in the Congo area. And, because of the French protectionist policy (and power), this was a greater threat than recognition of the (virtually powerless) AIC. Therefore, the Foreign Office reacted furiously and spoke of 'a shabby and mischievous trick' (Stengers, 1971: 162).

Meanwhile, a storm of protest had broken out regarding the Anglo-Portuguese treaty. In Portugal, trading houses and the very influential Sociedade de Geografia de Lisboa thought the treaty to be a humiliation for Portugal because the British recognition of the Portuguese territorial claims had been made extremely conditional (Axelson, 1967: 65-66). In Britain, various Chambers of Commerce as well as several Church and humanitarian organizations protested because of Portuguese protectionism and the inefficiency and corruption of the authorities in the Portuguese possessions (Anstey, 1962: 152-155). More decisive, however, were the protests from France and especially Germany. The French opposition was understandable because of her own interests in the region and her right of pre-emption regarding the AIC territories (Crowe, 1942: 24-25). On 7 June 1884, Bismarck sent a note to the British Foreign Office in which he declared the treaty to be unacceptable, as Portuguese sovereignty on the Lower Congo was too harmful for the trading interests of other nations. With this note, the British government had no other option than to abandon the ratification of the treaty with Portugal (Crowe, 1942: 32-33).

The German reaction was part of a general anti-British colonial policy that emerged in the course of 1883 and found a short culmination in 1884-85. The mere fact of Bismarck turning to such a policy came as rather a surprisc. 'So long as I am chancellor, we shall not pursue a colonial policy', he had stated repeatedly (Pogge von Strandmann, 1969: 145). But from the end of the $1870 \mathrm{~s}$, the call for a colonial policy became louder and louder. It had to do with the economic crisis that had started in 1873, hitting both industry and agriculture. Landowners, traders and industrialists all called for protectionist measures. In 1882 the crisis deepened. A real 'colonial movement' came into existence and it was clear that the government and the ruling political parties could no longer ignore the colonial propaganda (Geiss, 1976: 14-15, 46-47; Pogge von Strandmann, 1969: 141-142; Wehler, 1972: 79-80).

The first clear sign of the new German policy was Bismarck's negative reaction to the Anglo-Portuguese treaty (one year later Germany had annexed the coastlines of Cameroon, Togo, South-West Africa [Namibia] and German East Africa [Tanganyika]). Why was Bismarck's new policy anti-British? Most likely, there were two reasons for this. First, by pursuing an aggressive colonial policy - i.e. by making the outstanding imperialist power, Britain, a kind of Reichsfeind-Bismarck hoped to touch German nationalist sentiments and thus to win the general elections in October 1884. "[A]11 this colonial policy was undertaken simply as an election stunt', wrote Holstein, Bismarck's adviser at the Foreign 
Ministry, in September of that year (Pogge von Strandmann, 1969: 146). The second reason concerned the political relations with France. After the Franco-Prussian war (1870-71), and the German annexation of Alsace-Lorraine, Franco-German relations had been strained. Bismark's major foreign policy objective was directed at the political isolation of France in Europe. In practice, this meant that a liaison between France and Russia had to be averted. This was the main purpose of the complex alliance network Bismarck created during his long chancellorship. His anti-British colonial policy can also be judged in this context: because of the French-British rivalry on colonial issues (as for instance the Egypt question), the immediate result of Bismarck's changed attitude was a rapprochement with France - at least regarding colonial matters-in 1884 (Taylor, 1967: 29-31).

Of course, Bismarck had to prove that he was serious. He not only showed a very friendly attitude towards the French (Taylor, 1967: 20-21), but also supported France during the Egypt conference in London (June 1884) and agreed with France to force a settlement regarding West Africa and the Congo area. Based on a Portuguese suggestion (Latour da Veiga Pinto, 1972: 241-243), it was decided to organize an international conference on West Africa. At the request of the French prime minister, Ferry, territorial issues were not put on the agenda, because France preferred to deal bilaterally with the weak Portugal and the even weaker AIC. Both Ferry and Bismarck realized, however, that any convention regarding trade and navigation in the Congo area was worthless unless the territorial problems had also been settled (Crowe, 1942: 62-67; Taylor, 1967: 37, 45-48). These territorial discussions were held behind the scenes of the conference and proved to be so problematic that the final session of the conference could be held only three months later than foreseen.

Britain was not very eager to join the conference, partly because Ferry and Bismarck had put the navigation on the Niger on the agenda, while Britain regarded the Lower Niger as being 'British' in the same way as the French regarded the Senegal as 'French'. As the major imperialist power Britain had always settled colonial disputes bilaterally. By not accepting Bismarck's invitation to participate at the conference, however, Britain would manoeuvre herself into complete isolation. Shortly before the conference started, Bismarck again 'struck' the British by recongnizing the AIC as a sovereign power in November 1884. This was partly a consequence of the French right of pre-emption: it was better to place the AIC - which in the meantime had promised free trade for all nations in the area (Stengers, 1971: 149-150) - in the Congo than to have to deal with such protectionist powers as France or Portugal. Bismarck's move also fitted in with his colonial entente with France, because Ferry was positive about the recognition: Leopold's promise to guarantee complete free trade in the AIC territories meant that this new state would have no revenues, only making a future French purchase of the AIC possessions more likely. Moreover, Bismarck recognized a definite AIC territory which was extremely vast (Stengers, 1963: 174-179).

After Bismarck's recognition of the AIC, it was only a question of time before the Congo problem was settled. Britain had no other choice than to follow the German recognition, even though there were very controversial opinions on this point within the Foreign Office (Louis, 1971: 201-202). On 16 December 1884, the British government 'recognised the flag of the Association, and of the Free States under its administration, as the flag of a friendly Government' (Hertslet, 1967, II: 574). Ten weeks later, all participating states at the Berlin Conference (except Turkey) had signed a similar agreement (Crowe, 1942: 149). The Independent State of the Congo-or the Congo Free State as it was called-had become a political reality. 


\section{Explanations for the partition of Africa}

During the first three-quarters of the 19th century, the European policy towards Africa (as well as Asia) falls under the heading of informal imperialism, i.e. the creation and continuation of a structure of economic dominance. During the last decades of the century, however, this policy gave way to formal imperialism, aiming at direct political control by the European power of the territory of a weaker power (Art and Jervis, 1973: 292). The still independent parts of Africa and Asia were annexed with a speed that had never been seen before. It is understandable that many authors have tried to explain why this extraordinary phenomenon in European history took place. Some of the theories pretend to offer an explanation for not only the partition of Africa but for the whole late 19th-century's imperialism. Others are directly concerned either with Africa as a whole or with certain parts of the continent. Moreover, the more general theories apply to any political actor, while the more specific explanations usually refer to one actor. Finally, the theories differ according to line of approach. In the following presentation, they will be (briefly) discussed under four headings: economic explanations, political explanations, élitist explanations, and explanations from local (i.e. African) circumstances.

\section{Economic explanations}

The best-known general economic theory is what may be called the classical economic theory. States annex areas (or obtain informal control over other economies) because their economies need a secure source of raw materials, an export market for their industrial products and an outlet for surplus capital. The basic cause lies in the working of the capitalist system that is directed towards maximization of profits. In order to achieve that, wages are kept low. As a result, the purchasing power of the masses becomes too limited for the expanding industries to sell their products and to make new investments. Hence, outside markets have to be found in order to avoid over-production and underconsumption. Within this view, three variants can (or better: could) be distinguished (Morgenthau, 1978: 51-52). 'Radicals' like Lenin and Bukharin did not see imperialism as a political process but as a necessary phase of capitalism, i.e. the monopoly phase or, in Lenin's words, 'the highest stage of capitalism'. Imperialism was necessary in order to avoid the collapse of the capitalist system. For 'moderates' like Kautsky and Hilferding an imperialist policy was not just a reflection of economic forces, but did contain an element of choice, depending on specific circumstances. Finally, for 'liberals', of whom Hobson was the major representative, territorial expansion was not at all necessary to solve the problem of over-production and under-consumption. The solution had to be found in raising the purchasing power of the masses.

Since the beginning of the 1980s, this type of economic explanation has no longer been influential (see Etherington 1981, 1982, and, regarding Africa, Foeken, 1982). As far as the partition of Africa is concerned, two major weaknesses may be mentioned. First, overseas investments of the major imperialist powers in Africa (Britain, France and Germany) after 1900 did not go to Africa, and the small amount that was invested in that continent found its way to those areas that were already formally controlled before the partition started (mainly Egypt and South Africa). Not surprisingly, the trade parterns were similar (Foeken, 1982: 140-141). Second, of the five main imperialist powers in Africa, only one (Britain) had substantial overseas investments. French and German investments (together less than the British) found their way primarily within Europe, while Italy and Portugal suffered a severe shortage of capital during the partition (Foeken, 1982: 141-142). 
Despite these weaknesses, the theory may have some value as a motive for territorial expansion by the then politicians. According to Chirot, in the European industrial states there was a conviction of the necessity of an imperialist policy in order to safeguard a future as an industrial power. Territorial expansion was perceived as a vital interest and thus 'the main powers behaved as if it were indeed vital' (Chirot, 1977: 54). And Boahen, referring to the 'scramble' for colonies in Africa, argues that 'even if it is true that not much capital was invested in the colonies after their acquisition, it does not mean that originally the imperial powers did not have the hope of doing so' (Boahen, 1987: 30). One might call this explanation the psycbological variant of the classical economic theory. Certainly Leopold II and perhaps also Pierre Savorgnan de Brazza fit into this picture. Leopold's passion for colonial possessions served his country (Stengers, 1972: 267-270). Already in 1860 he stated to the government that 'Belgium requires a colony', The Netherlands' Indies being his prime example (Stengers, 1977: 57). Perhaps the most remarkable thing is that from the beginning to the end of his colonial adventures, i.e. roughly from 1860 to 1900 , he stood alone in his ambitions. Neither the Belgian state nor Belgian traders, industrialists or financiers showed any interest in a Belgian colony. The Belgian cconomy leaned strongly on the Walloonian heavy industry, which found easy outlets in the neighbouring European countries (Kurgan-van Hentenryk, 1988).

A second general economic theory can be labelled as the anarchistic theory, of which Robbins (1973) is the main proponent. It seeks the explanation for the late 19th century's imperialism in the anarchistic structure of the state system. In this view, capitalist states are best served by free trade in a Ricardian economic system, i.e. each state produces the products it is best suited for. In that way, free trade leads to international specialization and optimal advantages for each actor. However, because of the absence of a supranational control mechanism (i.e. the anarchistic structure of the international system), certain states do not comply with the rules and try to obtain advantages at the cost of others by means of creating trade barriers. Other states are thus forced to pursue an imperialist policy, in order to prevent economic losses. For Robbins, imperialism is a defensive action.

One of the specific explanations regarding the partition of Africa which is linked with this view concerns the so-called closed door tbeory. This theory has been developed in order to explain Germany's sudden participation in the partition. The economic recession that started in 1873 was also felt in West Africa (i.e. from Senegal to Lagos), which led to an increasing protection of the British and French trading interests in that area (Newbury, 1971). Moreover, in German industrial and trading circles an Anglo-French convention regarding West Africa was interpreted as if the whole west coast had been divided between these two powers, which meant that the German trading interests in the area were threatened (Turner, 1967: 51-56). The fear of finding the door to Africa (and Asia) closed induced Bismark to pursue a colonial policy. Although there may be some truth in this view, the German term for it, Torschlusspanik, seems strongly exaggerated. In reality, there was no question of German exclusion, but the fear that it might happen served as an argument for the colonial propagandists. The Anglo-French convention applied only to the part of the west coast from Senegal to Sierra Leone; moreover, it was never ratified. Of course, Germany's interest in Africa was primarily an 'open door', i.e. guarantees for free trade and free navigation. Bismarck's decision to reject the Anglo-Portuguese treaty and to recognize the AIC were undoubtedly-beside such 'higher' political goals as the rapprocbement with France and the German elections-related to the wish to secure an open door for German interests in the Congo area. A policy of formal imperialism, however, was not necessary to achieve this objective.

A third general economic theory is the world system approach that was designed by 
Wallerstein (see, e.g., Hopkins and Wallerstein, 1982) and in which elements from both the classical economic theory and the anarchistic theory can be found. The approach was further developed by, for instance, the political geographer Taylor (1989). Imperialism is related to two phenomena: the cyclical movements of economic growth and decline and the rivalry between the major powers. The economic cycles are based on the 'Kondratieff cycles', named after the Russian economist who was the first to describe these economic movements. Each cycle contains a period of about 50 years and consists of two stages: one of economic growth (A) and one of economic recession (B). The rivalry between major powers (or 'core states') is expressed in terms of 'hegemonic cycles' that last about 100 years. Each hegemonic cycle coincides with two Kondratieff cycles and the two movements are, at least for the 19th and 20th centuries, connected in the following way. During the first stage of economic growth (A1), core states are more or less equal. However, new technologies are concentrated in one state, giving it a productivity lead. This is the stage of 'rising hegemony' of that state. During the subsequent stage of economic recession (B1) there is little room for economic expansion, but the 'rising hegemonic power' acquires commercial superiority. In this stage it becomes clear which state will become the new hegemon. Taylor calls this the stage of 'hegemonic victory'. During the following stage of economic growth (A2), the hegemonic state, beside being already the industrial and commercial centre of the world, also becomes the financial heart and reaches hegemonic maturity'. In the final stage, i.e. of economic recession (B2), the hegemonic state has to face increasing competition from other powers, because of a decreasing productivity compared with others. This is the stage of 'declining hegemony'. At the end of this stage, there is no longer a clear hegemonic power, but during the subsequent stage of economic growth (a new A1 stage), a new 'rising hegemon' will come forward (Taylor, 1989: 63-66).

The period in which the partition of Africa took place was a B2 stage that lasted from 1873 to 1896 . Britain was the hegemonic power, but with the start of the economic recession the British hegemony began to decline. New industrializing powers (Germany, the United States), trying to challenge the British economic hegemony, 'needed, or felt they needed, large markets for their industries and access to raw materials' (Wallerstein, 1970: 103). As Taylor concludes, B2 stages 'are periods of protectionism and formal imperialism as each rival attempts to preserve its own portion of the periphery' (Taylor, 1989: 65). It cannot be denied that during the period that the partition of Central Africa took place (1875-85), economic rivalries between the major European powers were increasing: witness for instance the protectionist measures in Germany and France. But as to the extent that these rivalries played a role in the process of the partition, this may have occurred during the 1980s, when competition sometimes took the form of a 'scramble' for territories in Africa.

\section{Political explanations}

There is one general political theory that tries to explain imperialism from the dynamics of international power distribution. This is the balance of power theory, which was developed by historians such as Hinsley (1959) and Taylor (1954). In their view, the late 19th century's European imperialism can be considered as a safety-valve for the struggle for European hegemony between the great powers. In this way of thinking, a central role is assigned to Bismarck, who was German Chancellor as well as Foreign Secretary from 1862 to 1890 . After the Franco-Prussian war of $1870-71$, a united Germany became the strongest power on the Continent, and Bismarck's foreign policy was directed towards maintaining this situation. In concluding a whole range of treaties and agreements with other great 
powers, he tried to stabilize the European balance of power. This period is often called the 'Concert of Bismarck', as all important political agreements between the European great powers had their roots in Berlin. Bismarck's diplomatic activities had one major aim: to prevent a possible bond between France and Russia. In this context, Bismarck's sudden entry, in 1884, into the partition of Africa can be regarded as a step in European power diplomacy. By means of an aggressive colonial policy, Britain-the major imperialist power and as such, potentially, the main obstacle to the German Weltpolitik-was to be put under pressure and forced into a political agreement with Germany. The ultimate aim was the political isolation of France. In Bismarck's own words: 'My map of Africa lies in Europe. Here lies Russia and here lies France, and we are in the middle. That is my map of Africa' (Taylor, 1954: 294).

It cannot be denied that these observations certainly were an important factor in Bismarck's decision to take part in the partition of Africa. As we have seen, however, national considerations in the form of the German general elections also played a role. Moreover, can one 'blame' Bismarck for setting in motion the partitioning process? The answer must be negative. Bismarck's aggressive colonial policy lasted only one year, during which he annexed four pieces of the African coast. After 1885 the partition of Africa came to a relative standstill, to be renewed some five years later.

Also the theory of social imperialism was developed-by Wehler (1970, 1972)-to explain Bismarck's imperialism. Unlike the former explanation, however, it seeks an explanation in the dynamics of the national instead of the international distribution of power. Territorial expansion is seen as a political means to face internal social unrest, which manifests itself through increasing class conflicts in periods of rapid industrial development. According to Wehler, in Bismarck's Germany there was social unrest, which was caused primarily by the unsteady growth that characterized the German economic development in the period 1873-96: periods of very rapid industrialization were alternated with various industrial crises $(1873-79,1882-86,1890-95)$, while the recession in the agricultural sphere, starting in 1876, appeared to be structural. The ensuing social unrest formed a direct threat to the existing ruling class. A new foreign policy, directed at formal imperialism, was used as a crisis ideology and served two ends: as a therapy for the economic recession and as a diversion from the social troubles (and thus serving as a means to sustain the existing socio-economic structure). In that way, 'social imperialism' worked as a safety-valve to counteract the sharp class contrasts caused by rapid but unsteady industrialization. For Wehler, the maintenance of the traditional power structure, with Bismarck at the top, was the leading motive behind his colonial policy.

If staying in power is translated into winning elections, we have seen that this undoubtedly played a role in Germany's turn to formal imperialism. But again, this is only part of Bismarck's story. The old debate in the literature on international relations regarding the primacy of either national or international causes of foreign policy behaviour turns out to be a mixture of both.

As far as Portuguese imperialism during the last quarter of the 19th century is concerned, one might present the same reasoning as Wehler did for Germany. The elements of this reasoning are offered by Clarence-Smith $(1985,1988)$. In the 1870 s, the industrialization process in Portugal (and also Spain) had just started, so the economy was still based largely on agriculture. Therefore, the economic recession that started in 1873 was felt much harder than in Northern Europe. Both the internal and the export markets were being swamped by cheap agricultural products from, for instance, the United States and Russia. Beginning industries could not cope with the strong competition and the merchant fleet threatened to be washed away. Hence, the call for protection of the internal 
market and secure export markets became ever louder (Clarence-Smith, 1988: 216-217). According to Clarence-Smith, this shows that the imperialism of the two Iberian states was a form of economic imperialism. Yet, regarding the Portuguese expansion, non-economic motives also played a role. The economic depression caused a growing dissatisfaction in the country, in particular among the urban middle class and labourers. This was a direct political threat for the Portuguese leaders, who turned to the use of nationalist ideas, to be employed 'as the most effective counter-ideology against urban radicalism' (ClarenceSmith, 1988: 217). And because of Portugal's history of almost four centuries of colonialism, it was only logical to appeal to the 'heroic past' as the major cornerstone of this nationalism (Clarence-Smith, 1985: 82). In other words, a renewed Portuguese expansionist policy not only served an economic but also a political goal.

\section{Elite explanations}

In this category of explanations, certain characteristics of the ruling élites reveal the causes of imperialist policies. The most important representative of the 'elitists' is Schumpeter (1973). Opposing the Marxist theories, he argues that capitalism 'by its nature' is anti-imperialistic: trade does not benefit from disturbances of the political status quo, let alone by conquests or war: 'it is a basic fallacy to describe imperialism as a necessary phase of capitalism, or even to speak of the development of capitalism into imperialism' (Schumpeter, 1973: 375). The reason that states are nevertheless imperialistic has to do with the composition of the political élite. In Schumpeter's view, imperialistic states are ruled by an élite that still partly shows characteristics from the earlier monarchistic, autocratic system: it is not the liberal merchant spirit that dominates, but nationalism and militarism. According to this sociological theory, imperialism is a goal in itself and only serves the interests of the so-called 'warrior class' (Schumpeter, 1973: 378-380).

There are two specific theories regarding the partition of Africa that are in a sense related to this general viewpoint. The first one is the mytbical theory, which was developed by Kanya-Forstner (1972) and which refers to the French expansion in Africa. According to this theory, French expansion in West Africa and towards the Ipper Nile was hased on 'illusions' on the part of the responsible politicians. In western Africa, the reputed richness of the interior might explain the French striving for a large African empire. The expansion towards the Upper Nile, which took place in 1894-98 and which was meant to put pressure on Britain so that she would agree to an international conference regarding Egypt, was based on two expectations that turned out to be illusions: support of other powers (Germany, Russia, Ethiopia) and a diplomatic reaction by the British (Andrew and Kanya-Forstner, 1975). According to Kanya-Forstner, the causes of the existence and persistence of such 'myths' should be found in the character of French decision making: the great autonomous power of the Colonial Department; the very frequent alternations of the responsible politicians, who, therefore, lacked much sense of responsibility; the personal influence of the decision makers; the prevailing ideology in French foreign policy (anti-British); the influence of public opinion and colonial-minded pressure groups; and, last but not least, bad and incomplete information, for which the decision makers were largely dependent on the Anglophobe expansionists in the field, the officiers soudanais (Kanya-Forstner, 1972: 285-291). Incidentally, these 'Sudan officers' can be considered as representatives of the French 'warrior class'.

On close inspection, the mythical theory can be summarized in terms of two concepts that are of utmost importance in each decision-making process: (dis)information and (mis)perception. Foreign policy is full of examples of insufficient or unreliable 
information and of false perceptions. This is pertinent also to the policy of the actors in the partition of Africa. Thus, it is somewhat exaggerated to speak of a 'mythical' theory. The story of the partition of Central Africa also contains many examples of disinformation and misperception. Perhaps the biggest misperception (on the part of all European powers) was the expectation-if not conviction-that Leopold's 'adventure' would fail.

The second specific theory that can be considered as an élitist explanation concerns the so-called prestige imperialism. In this view, territorial expansion is fed by feelings of national consciousness and national pride. Thus, imperialism becomes a goal in itself. According to Hess (1967), the Italian expansion is an example of this imperialism variant. Like Germany, Italy had never shown any colonial aspirations; not even after the French occupation of Tunisia-where some 50000 Italian colonists had settled-in 1881 . However, after Bismarck's decision to annex certain parts of Africa, some Italian politicians became convinced that Italy, as a great power, could not stay behind. In Hess's words: 'Colonialism was not to be solely a French and British phenomenon. Germany has acted; Italy must act' (Hess, 1967: 153).

Some authors consider the Portuguese imperialism also as a form of prestige imperialism (Axelson, 1967; Hammond, 1966). Whether this is right or not (compare Clarence-Smith's viewpoint above), the fact that the imperialist policy of the Portuguese government was, amongst others, justified by appealing to the heroic colonial past gave it an undeniably prestigious character. The recognition of her territorial claims at the Congo mouth was not in the least considered to be a question of honour. Moreover, interference with Portuguese colonial afairs was vehemently rejected.

Finally, Leopold's striving for a large imperium in Central Africa can also be judged as a matter of prestige; not primarily for himself but for the sake of Belgium. Notwithstanding the fact that he must have been convinced of the future economic importance of a colony, one can hardly but believe that at least in part he was driven by prestigious feelings. Otherwise it is very difficult to understand why, during his whole colonial campaign in Central Africa, not a single politician or businessman was willing to back him.

\section{Explanations from local circumstances}

All theories and explanations that have so far been dealt with consider the late 19th century's imperialism from a European perspective. There are authors, however, who stress that circumstances on 'the periphery' have also been an explanatory variable. Some even speak of the 'missing key' in the imperialism debate (Robinson, 1972: 119-120). The central element in these analyses is the threat to already existing interests of the imperialist power in the area concerned. A representative of this 'security explanation' is Galbraith (1973). In his description of the turbulent frontier as a factor in British imperialism, he shows that during the first three-quarters of the 19th century-when liberalism and informal imperialism reigned unchallenged-the British territorial expansion in India, Malaysia and South Africa was induced by regular threats to British interests and security along the borders of the empire. A comparable reasoning is found in Betts (1975), albeit for the last quarter of the 19th century, i.e. including the partition of Africa, and not only regarding Britain. After it had started, territorial expansion did not take place 'at random': 'the geographical factor of contiguity was operative almost everywhere'. However, in his opinion the annexation of adjoining areas was not justified by security motives: 'the proximity of unsubmitted lands was a provocation to worry and a source of temptation' (Betts, 1975: 82).

However useful such analyses may be, one must realize that they can at best explain 
certain actions by certain actors. And they cannot explain why territorial expansion in a certain area started. Galbraith admits this 'weakness'. With his 'turbulent frontier' he does not pretend to offer the explanation for the British expansion during the first three-quarters of the 19th century, 'but rather to call attention to the importance of a sometimes neglected factor which influenced policy to varying degrees in different areas of the British Empire' (Galbraith, 1973: 414).

The first 'theory' that can be considered as an explanation for the partition of Africa from local circumstances was the strategical theory of Robinson and Gallagher (1965). These authors consider the British occupation of Egypt in 1882 as the main cause of the partition. Although de jure under Turkish suzerainty, Egypt was de facto politically independent until 1875. In that year, the country went bankrupt. This induced Britain and France to exert combined control of Egyptian finances in order to defend their financial interests (e.g. the Suez Canal Company). In the following years, a growing dissatisfaction of the combined Egyptian élites with the British and French tutelage led to a rebellion. Britain decided to intervene and in less than two months the country was occupied (Owen, 1972: 198-206; Ramm, 1971: 86-110). Following the British military action, talks between France and Britain about the termination of the condominium failed, which deprived France of any compensation for the British occupation. Not only did this end the Anglo-French cooperation regarding Egypt, but now the foundation was laid for the partition of Africa and the Anglo-French rivalries therein (Robinson and Gallagher, 1965: 465). Regarding South Africa, they put forward similar arguments. Here also, an internal crisis-Afrikaner nationalism-endangered the existing status quo. And again, British interests, direct (trade, mining) as well as indirect (the route to India in the event of problems with the Suez Canal), had to be defended. Here, however, the British reaction was less violent than in Egypt. By indulging the expansionist tendencies of the Cape Colony government, the British government was hoping to prevent a break between a possible South African Union (after the example of the United States) and the British Empire. In short, 'nearly all the interventions appear to have been consequences, direct or indirect, of internal Egyptian or South African crises which endangered British influence and security in the world' (Rohinson and Gallagher, 1965: 465). But, as for the rivalries between the European powers during the partition, the authors consider the occupation of Egypt as the main cause, and even dare to say that 'without the occupation of Egypt, there is no reason to suppose that any international scrambles for Africa, either west or east, would have begun when they did' (Robinson and Gallagher, 1965: 163).

Robinson and Gallagher's theory suggests that the French territorial expansion in Africa was simply motivated by a search for compensation due to the 'loss' of Egypt. One cannot deny that Anglo-French rivalry in Africa lasted as long as the partition endured. Even in Central Africa, which had no strategic importance for Britain, it may have played some role: there are indications that the French convention with Leopold of April 1884, in which France obtained the right of pre-emption, was, amongst others, the result of the French fear that if Leopold should be forced to dispose of his African possessions it would fall into the hands of the British (Stengers, 1971: 155-157). On the other hand, the French decision to acquire a colony in the Congo area should primarily be seen as a renewed search for the old French grandeur (which is not necessarily the same as compensation for Egypt) and cannot easily be related to Anglo-French rivalry.

Finally, the collaboration theory, as designed by Robinson (1972), can be considered as a variant of the former explanation. It simply states that the conquest and administration of the colonial areas would not have been possible without the collaboration of certain élites in those areas. He uses the example of Egypt: a 'shortage' of reliable 'collaborators' forced 
the British government to intervene in 1882 (Robinson, 1972: 131). As a co-explanation for the success of the European annexation of Africa on such a scale and in such a short time, the collaboration idea is certainly useful. It raises the question of why the indigenous rulers were willing to cooperate with the 'intruders' (Wesseling, 1991: 127). Boahen (1987: 36-38) provides a first, tentative answer. The friendly attitude of the African rulers towards the Europeans during the first stage of the partition of Africa-i.e. the stage of concluding treaties with the African leaders-had several causes. First, in the beginning the African chiefs were treated as equals and with respect. Second, many indigenous rulers could derive benefit from European protection against neighbouring rivals or even against their own subjects. Third, many African leaders were attracted by the future trading perspectives. And finally, in some cases, alcohol, exuberant gifts and deceit played a role. Still, one can ask whether the partition of Africa would have been abandoned in the face of widespread African resistance. The partition would only have taken more time. One should not forget that French West Africa was annexed mainly by military means. In sum, the collaboration idea is not very useful for the explanation of the partition of Africa.

\section{Conclusions}

All the theories that have been discussed do not advance us much in explaining $w b y$ the partition of Central Africa took place. Some of the theories put forward the motives of three of the five actors involved in this particular partition process: Germany, Portugal and Leopold II. Specific explanations for the British expansion do not apply in this part of Africa. However, two related motives for the British role can be mentioned: in the first place, the situation of free trade that had always existed in this area had to be defended and, second, as protector and ally of the weak Portugal a certain responsibility was felt in London towards Lisbon. This was shown, for instance, by the British willingness to discuss the Portuguese territorial claims earlier than 1876, i.e. long before the Portuguese claims were threatened by France and the AIC. However, this offered the British government the opportunity to demand better trading conditions in the Portuguese colonies. From the course of the repeated and lengthy Anglo-Portuguese negotiations between 1876 and 1884, one can only conclude that for the British the first motive (free trade) was more important than the second (responsibility towards Portugal).

Regarding the background of the French expansion, the above-mentioned theories do not offer much support. It is better to combine the answer to the question of the French motives with two other questions: 'why there?' and 'why then?'. Or, more concretely: why did a process of European territorial expansion in Central Africa start in 1876? That process was instigated by two men: Leopold II and Pierre Savorgnan de Brazza, two individuals who not only thought but also acted imperialistically. Both could dispose of the necessary means (Leopold from his own funds, Brazza through the aid of Montaignac) with which to realize their ideals. Why their expansion took place in the Congo region had to do with the great interest in this area which existed around 1875 in geographical circles (Leopold) and with Brazza's secondment to the South Atlantic squadron of the French navy.

One might consider these two gentlemen as representatives of Schumpeter's 'warrior class', i.e. the élite that was characterized by nationalism and militarism and for whom imperialism was a goal in itself. That does not mean that I subscribe to his sociological theory. Neither in France nor in Belgium was such an élite in power at the time. Both Leopold and Brazza were individuals, who, more or less 'by accident', were in a position to bring their imperialist ideas into practice in this part of the world.

Still, we have not yet given the answer to the question of $w b y$ the partition of Central 
Africa took place. 'Who wants to give an answer to the question why the partition took place when it took place, cannot limit himself to people and their motives, but has to deal with causes' (Wesseling, 1991: 455). More concrete questions in this context are, for instance: why did the French government reject support for Brazza's second expedition in 1879, while three years later he was sent out to found nothing less than a French colony?; and why did Bismarck always reject a German colonial policy, while in 1884-85 he annexed four parts of Africa in 10 months? To the extent that the causes of the partition are discussed in the literature, it is usually in a very limited way. It is only in the final chapter of their book that Robinson and Gallagher (1965: 466) mention the 'deeper causes' of the partition. Sanderson (1975: 18-20) speaks of 'changing stabilizing factors', while Kanya-Forstner (1972; 277-278) uses the word 'conditions'. Whatever the terms that are used, in general three factors are distinguished: industrial and technological changes, changes in the European power distribution, and ideological changes. The first factor has to do with developments in transport (navigation, railways) and communication (telegraph) which made expansion possible at a scale that was unthinkable beforehand. The second factor is related to the increasing economic and political rivalry between the European great powers during the last quarter of the 19th century. Several of the general economic and political theories deal with this set of changes: the anarchistic theory focuses on the economic rivalry, the balance of power theory on the political rivalry, while the world system approach deals with both. The third factor (ideological changes) is related to the transition from liberalism to an ideology based on nationalism and racism (under the influence of social Darwinism). The sociological theory is linked with this set of changes, as it tries to explain European imperialism by reference to certain ideological characteristics of the ruling élites.

Thus, in order to answer the question of why a process of European territorial expansion started in 1876 in Central Africa, it is essential to determine exactly when these changes took place and when the expansion process started. Moreover, I shall try to demonstrate that the answer to the question also depends on how one defines imperialism.

When did the partition of Africa start? For some it was in 1882 , when the British occupied Egypt. For others it was 1884, when Germany entered the picture. According to Boahen (1987: 32), however, the partition started in 1879, as in that year three 'starting shots' were 'fired': (a) three French missions to explore routes for the trans-Sahara railway; (b) the appointment of Major Gustave Borgnis-Desbordes as the commander of Upper Senegal to push French imperial interests inland; and (c) the start of the penetration of the Congo area by Stanley and Brazza. The latter 'starting shot' also denotes the start of the actual partition of Central Africa, although one must not forget that already from 1876 onwards Leopold was developing his plans for creating a colony (or at least a trading monopoly) in this part of Africa and for two years had already been busy trying to realize this by sending Belgian expeditions to East Africa. Hence, for Pakenham (1991: xxv) the 'scramble' started in 1876. The whole partitioning process in Central Africa between 1875 and 1885 can be subdivided into four stages:

1. 1875-79: penetration of Central Africa by Leopold from the east and by Brazza from the west, both on personal title; the penetration is directed towards exploration, not annexation;

2. 1879-82: both Leopold and Brazza penetrate Central Africa from the west, still on personal title; the penetration is directed towards obtaining exclusive rights;

3. 1883-84: Brazza penetrates formally in the name of France; main objective of both Leopold and France is to obtain sovereign rights; Portugal and Britain step in; 
conflicting territorial claims between Leopold on the one hand and France and Portugal on the other;

4. 1884-85: the partition of Central Africa has become an issue in European diplomacy; guided by Germany, the conflicts are solved by diplomatic means.

The importance of this time-scale is related to the question of how one defines imperialism. Leaving aside the purely economic meaning for what it is, two definitions can be distinguished. The first is the one that is commonly used by political scientists. For them, imperialism is a foreign policy directed towards obtaining formal or informal (mostly economic) dominance over other societies (see, for instance, Holsti, 1983: 133; Morgenthau, 1978: 49; Russett and Starr, 1985: 213). Thus defined, only sovereign states can be imperialistic. Strictly speaking then, the partition of Central Africa started in 1882, i.e. after the ratification of the Brazza-Makoko treaties by the French parliament. The ratification had three important effects: (a) a real scramble in the Kwilu-Niari area and along the Upper Congo; (b) Portugal and Britain entered the stage in order to secure the Portuguese territorial claims and the British trading interests; and (c) a diplomatic offensive by Leopold for recognition of his AIC as a sovereign power. In other words, after the ratification the partition of Central Africa had become part of the foreign policy of several European powers. Each state, including Germany, tried to secure her (perceived) interests in this part of Africa. If one poses the question why at the end of 1882 a situation of European rivalry developed in Central Africa, all general theories offer at least some explanation. Although the economic stagnation began in 1873, it was from 1882 onwards that it was felt seriously. As a consequence, the call for protectionism in countries like France, Portugal and Germany became louder (anarchistic theory, world system approach). In 1882, Bismarck created his Triple Alliance (Berlin/Vienna/Rome), while the year before the Three Emperors' Alliance (Berlin/Vienna/St Petersburg) was established. France was isolated and in the vision of Bismarck had to remain so (balance of power theory). In France some ardent 'imperialists' like Ferry had come into power (sociological theory). Finally, in 1882 Britain occupied Egypt (strategical theory).

The problem with the above-mentioned definition of imperialism is that, for instance, the activities of Leopold II do not fit into it. Leopold acted as a private person, not in the name of the Belgian state. Therefore, I prefer a definition such as that of the Dutch historian Kuitenbrouwer (1985: 8), for whom imperialism is 'the purposive and actual effort to establish formal or informal dominance over another society'. Defined in this way, expansion in Central Africa started in 1879. And then the general theories do not advance much further. In the second half of the 1870 s there was no strong economic or political rivalry between the European major powers, while liberalism was still flourishing. The changes discussed above began to reveal themselves after 1880. This leads to the conclusion that the general theories regarding the partition of Africa cannot explain why European expansion started in the second half of the 1870s. In the first instance, it was a play for two gentlemen: Leopold and Brazza.

We can draw a second conclusion from the foregoing. If we want to explain the result (and not the start) of the European expansion in Central Africa, the general theories are certainly useful. The result is defined as the outcome of a series of political decision-making processes, i.e. the partition treaties concluded between the European actors involved. Then we are dealing in particular with the $1882-85$ period, a period when the above-mentioned changes began to develop. Although these decision-making processes were influenced by a whole range of factors (on the international, national and individual levels), changes in the European power structure and ideological changes played an important role. 
Finally, an analysis based on political decision making brings the stronger and the weaker aspects of the theories to the fore. Each theory contains elements which, for a certain actor and at a certain moment, may have been decisive in the process of decision making. However, no theory can be considered as the sole truth. Political decisions are seldom based on one single consideration, but it is always difficult to determine the relative weight of the various alternatives. As we have seen, Bismarck's decision in 1884 to turn to an expansionist foreign policy was based on both international and national considerations. What is clear, however, is that by carefully analysing bow the European process of territorial expansion passed, statements about why it took place can be better supported. This is a political-geographical research area par excellence.

\section{References}

ANDREw, C. M. AND KANYA-ForstneR, A S. (1975). General Hanotaux, the Colonial Party and the Fashoda strategy. In European Imperialism and the Partition of Africa (E. F. Penrose ed.) pp. 55-104. London: Frank Cass.

ANSTEY, R. (1962). Britain and the Congo in the Nineteenth Century. Oxford: Clarendon Press.

ART, R J. AND JERVIS, R. EDS (1973). International Politics. Anarchy, Force, Imperialism. Boston: Little, Brown. ASCHIRSON, N. (1963). The King incorporated; Leopold II in the Age of Trusts. London: George Allen \& Unwin.

AxElson, E. (1967). Portugal and the Scramble for Africa, 1875-1891. Johannesburg: Witwatersrand University Press.

BETTS, R. F. (1975). The False Dawn. Eunopean Imperialism in the Nineteenth Century. Minneapolis: University of Minnesota Press.

BOAHEN, A. A. (1987). African Perspectives on Colonialism. Baltimore/London: Johns Hopkins University Press.

BonTINCK, F. (1966). Aux origines de l'Etat Indépendant du Congo. Documents tirés d'arcbives américains. Leuven: Editions E. Nauwelaerts.

BRown, R. (1894). The Story of Africa and its Explorers, Vol. III. London: Cassell.

BRUNSCHWIG, H. (1963). L'Auenement de l'Afrique noire, du XIX' siècle à nos jours. Paris: Librairie Armand Colin.

BRUNSCHWIG, H. (1965). La négociation du traité Makoko. Cabiers d'Etudes Africaines 17(V), 5-57.

BRUNSCHWG, H. (1966). French Colonialism 1871-1914; Myths and Realities. London: Pall Mall Press.

Burdo, A. (1886). Les Belges dans l'Afrique centrale, Tôme III: De Zanzibar au Lac Tanganika. Brussels: P. Maes. CHIROT, D. (1977). Social Change in the Twentieth Century. New York: Harcourt Brace Jovanovitch.

Clarence-Smith, G. (1985). The Third Portuguese Empire, 1825-1975. A Study in Economic Imperialism. Manchester: Manchester University Press.

Garence-Smith, G. (1988). The Portuguese and Spanish roles in the Scramble for Africa: an economic interpretation. In Bismarck, Europe and Africa. The Berlin African Conference, 1884-1885 and the Onset of Partition (S. Förster, W. J. Mommsen and R. Robinson eds) pp. 215-227. Oxford: Oxford University Press.

COQUERY-VIDrovitch, C. (1969). Brazza et la prise de possession du Congo. La mission de louest africain, 1883-1885. Paris: Mouton.

CROWE, S. E. (1942). The Berlin West African Conference, 1884-1885. London/New York: Longmans.

n'UJRsFi., H. (1893). Les Belges au Tanganika. Bulletin de la Société Royale Belge de Géographie XVII, 75-96.

ELWTT, S. H. (1975). The Making of the Third Republic: Class and Politics in France, 1868-1884. Baton Rouge: Louisiana State University Press.

ETHERINGTON, N. (1981). Reconsidering theories of imperialism. History and Tbeory 20(1), 1-36.

ETHERINGTON, N. (1982). Theories of Imperialism: War, Conquest and Capital. London/Canberra: Croom Helm.

FOEKEN, D. W. J. (1982). Explanations for the partition of sub-Saharan Africa, 1880-1900. Tijdscbift voor Economische en Sociale Geografie 73(3), 138-148.

Galbrarth, J. S. (1973). The 'turbulent frontier' as a factor in British expansion. In International Politics. Anarcby, Force, Imperialism (R. J. Art and R Jervis eds) pp. 395-415. Boston: Little, Brown.

GeIss, I. (1976). German Foreign Policy, 1871-1914. Boston/London: Routledge and Kegan Paul.

Grant EuIOTT (1886). Exploration et organisation de la Province du Kwilou-Niadi. Bulletin de la Société Royale Belge de Géograpbie X, 101-114.

HAMMOND, R. J. (1966). Portugal and Africa, 1815-1910. A Study in Uneconomic Imperialism. Stanford: Stanford University Press.

Hertslet, E. (1967). The Map of Africa by Treaty, Part II and Part III (reprint of 1909). London: Frank Cass.

Hess, R. L. (1967). Germany and the Anglo-Italian colonial entente, In Britain and Germany in Africa (P. Gifford and W. R. Louis eds) pp. 153-178. New Haven: Yale University Press. 
HiNSI.EY, F. H. (1959). International rivalry in the colonial sphere, 1869-1885. In The Cambridge History of the British Empire, III, pp. 95-126. Cambridge: Cambridge University Press.

Holst1, K. J. (1983). International Politics. A Framework for Analysis, 4th edn. London: Prentice Hall.

HoPkunS, T. K AND WalersteIN, I. EDS (1982). World-systems Analysis: Theory and Methodology. Beverly Hills: Sage Publications.

KANYA-FORSTNER, A. S. (1972). French expansion in Africa: the mythical theory. In Studies in the Theory of Imperialism (R. Owen and B. Sutcliffe eds) pp. 277-294. London: Longman.

KuITENBROUwER, M. (1985). Nederland en de opkomst van bet moderne imperialisme. Koloniën en buitenlandse politiek 1870-1902 ("The Netherlands and the Rising of Modern Imperialism. Colonies and Foreign Policy 1870-1902'). Arnsterdam: De Bataafsche Leeuw.

KuRgan-van HentenRyK, G. (1988). Les milieux d'affaires belges et l'outre-mer vers 1985. In Bijdragen over de bonderdste verjaring van de Onafbankelijke Kongostaat/Le centenaire de l'Etat Indépendant du Congo, pp. 461-465. Brussels: Koninklijke Academie voor Overzeese Wetenschappen/Académie royale des Sciences d'Outre-Mer.

Latour DA VeIGa PINTo, F. (1972). Le Portugal et le Congo au XIX siècle. Etude d'bistoire des relations internationales. Genève: Université de Genève, Institut Universitaire de Hautes Etudes Internationales.

LouIs, W. R. (1971). The Berlin Congo Conference. In France and Britain in Africa (P. Gifford and W. R. Louis eds) pp. 167-220. New Haven: Yale University Press.

Morgenthuu, H. J. (1978). Politics Among Nations: The Struggle for Power and Peace, 5th edn. New York: Knopf. NewBuRY, C. W. (1971). The tariff factor in Anglo-French West-African Partition. In France and Britain in Africa (P. Gifford and W. R. Louis eds) pp. 221-259. New Haven: Yale University Press.

NewBury, C. W. (1988). On the margins of empire: the trade of western Africa, 1875-1890. In Bismarck, Europe and Africa. The Berlin African Conference, 1884-1885 and the Onset of Partition (S. Förster, W. J. Mommsen and R. Robinson eds) pp. 35-58. Oxford: Oxford University Press.

OwEN, R. (1972). Egypt and Europe: from French expedition to British occupation. In Studies in the Theory of Imperiulism (R. Owen and B. Sutcliffe eds) pp. 195-209. London: Longman.

PakENhiAM, T. (1991). The Scramble for Africa: the White Man's Conquest of the Dark Continent from 1876 to 1912. New York: Random House.

Pogge von Strandmann, H. (1969). Domestic origins of Germany's colonial expansion under Bismark. Past and Present 42, 140-159.

RAMM, A. (1971). Great Britain and France in Egypt, 1876-1882. In France and Britain in Africa (P. Gifford and W. R. Louis eds) pp. 73-120. New Haven: Yale University Press.

RobBins, L. (1973). Defensive economic imperialism. In International Politics. Anarcby, Force, Imperialism (R. J. Art and R. Jervis eds) pp. 311-321. Boston: Little, Brown.

ROBINSON, R. (1972). Non-European foundations of European imperialism: sketch for a theory of collaboration. In Studies in the Theory of Imperialism (R. Owen and B. Sutcliffe eds) pp. 117--142. London: Longman.

Robinson, R. E. AND GALAGHER, J. (WTTH A. DENNY) (1965). Africa and the Victorians, the Official Mind of Imperialism. London: Macmillan.

ROEYKENS, A. (1958). Léopold II et l'Afrique 1855-1880. Escai de synthèse et de mise au point. Brussels: ARSC.

Russetr, B. AND STARr, H. (1985). World Politics. The Menu for Cboice, 2nd edn. New York/Oxford: W. H. Freeman.

SANDERSON, G. N. (1975). The European partition of Africa: coincidence or conjuncture? In European Imperialism and the Partition of Africa (E. F. Penrose ed.) pp. 1-54. London: Frank Cass.

SANDERsun, G. N. (1988). British informal empire, imperial ambitions, defensive strategies, and the Anglo-Portuguese treaty of February 1884. In Bismarck, Europe and Africa. The Berlin African Conference, 1884-1885 and the Onset of Partition (S. Förster, W. J. Mommsen and R. Robinson eds) pp. 189-214. Oxford: Oxford University Press.

SCHUMpeter, J. (1973). The sociology of imperialisms. In International Politics. Anarcby, Force, Imperialism (R. J. Art and R. Jervis eds) pp. 364-382. Boston: Little, Brown.

Stantey, H. M. (1885). The Congo and the Founding of its Free State: a Story of Work and Exploration, 2 vols. London: Sampson Low, Marston, Searle, \& Rivington.

Stengers, J. (1963). Léopold II et la fixation des frontières du Congo. Le Flambeau (Revrue Belges des Questions Politiques et Littéraires) 46(3/4), 153-197.

STENGERS, J. (1971). King Leopold and Anglo-French rivalry, 1882-84. In France and Britain in Africa (P. Gifford and W. R. Louis eds) pp. 120-166. New Haven: Yale University Press.

STENGERS, J. (1972). King Leopold's imperialism. In Studies in the Theory of Imperialism (R Owen and B. Sutcliffe eds) pp. 248-276. London: Longman.

Stengers, J. (1977). Leopold II et le modèle colonial hollandais. Tijdscbrift voor Gescbiedenis 90, 46-71.

TAYLOR, A. J. P. (1954). The Struggle for Mastery in Europe, 1848-1918. Oxford: Clarendon Press. 
TAYLOR, A. J. P. (1976). Germany's First Bid for Colonies, 1884-1885. A Move in Bismarck's Eumopean Policy, reprint. New York: Archon Books.

TAYLoR, P. J. (1989). Political Geography. Worldeconomy, Nation-state and Locality, 2nd edn. Harlow: Longman. Thomson, R. S. (1933). Fondation de l'Etat Indépendent du Congo. Un chapitre de l'bistoire du partage de l'Afrique. Brussels: Office de Publicité (J. Lebègue \& Cie).

TURNER, H. A (1967). Bismarck's imperialist venture: anti-British in origin? In Britain and Germany in Africa (P. Gifford and W. R. Louis eds) pp. 47-82. New Haven: Yale University Press.

WALLERSTEIN, I. (1970). The colonial era in Africa: changes in the social structure. In Colonialism in Africa 1870-1960, vol. 2 (L. H. Gann and P. Duignan eds) pp. 399-421. Cambridge: Cambridge University Press.

Wekller, H. U. (1970). Bismarck's imperialism 1862-90. Past and Present 48, 119-155.

WEHLER, H. U. (1972). Industrial growth and early German imperialism. In Studies in the Theory of Imperialism ( $R$. Owen and B. Sutcliffe eds) pp. 71-92. London: Longman.

Wesseling, H. L. (1991). Verdeel en beers. De deling van Afrika, 1880-1914 ('Divide and Rule. The Partition of Africa, 1880-1914'). Amsterdam: Bert Bakker. 